\title{
REGIONAL EXTENT OF AN ECOSYSTEM ENGINEER: EARTHWORM INVASION IN NORTHERN HARDWOOD FORESTS
}

\author{
Andrew R. Holdsworth, ${ }^{1,3}$ Lee E. Frelich, ${ }^{2}$ and Peter B. Reich ${ }^{2}$ \\ ${ }^{1}$ University of Minnesota, Conservation Biology Graduate Program, 187 McNeal Hall, 1985 Buford Avenue, \\ St. Paul, Minnesota 55108 USA \\ ${ }^{2}$ University of Minnesota, Department of Forest Resources, 1530 North Cleveland Avenue, St. Paul, Minnesota 55108 USA
}

\begin{abstract}
The invasion of exotic earthworms into northern temperate and boreal forests previously devoid of earthworms is an important driver of ecosystem change. Earthworm invasion can cause significant changes in soil structure and communities, nutrient cycles, and the diversity and abundance of herbaceous plants. However, the regional extent and patterns of this invasion are poorly known. We conducted a regional survey in the Chippewa and Chequamegon National Forests, in Minnesota and Wisconsin, USA, respectively, to measure the extent and patterns of earthworm invasion and their relationship to potential earthworm introduction sites. We sampled earthworms, soils, and vegetation in 20 mature, sugar mapledominated forest stands in each national forest and analyzed the relationship between the presence of five earthworm taxonomic groups, habitat variables, and distance to the nearest potential introduction site. Earthworm invasion was extensive but incomplete in the two national forests. Four of the six earthworm taxonomic groups occurred in 55-95\% of transects; however $20 \%$ of all transects were invaded by only one taxonomic group that has relatively minor ecological effects. Earthworm taxonomic groups exhibited a similar sequence of invasion found in other studies: Dendrobaena $>$ Aporrectodea $=$ Lumbricus juveniles $>L$. rubellus $>$ L. terrestris. Distance to the nearest road was the best predictor of earthworm invasion in Wisconsin while distance to the nearest cabin was the best predictor in Minnesota. These data allow us to make preliminary assessments of landscape patterns of earthworm invasion. As an example, we estimate that $82 \%$ of upland mesic hardwood stands in the Wisconsin region are likely invaded by most taxonomic groups while only $3 \%$ are unlikely to be invaded at present. Distance to roads and cabins provides a coarse-scale predictor of earthworm invasion to focus stand-level assessments that will help forest managers better understand current and potential forest conditions and identify uninvaded areas that could serve as important refugia for plant species threatened by earthworm invasion.
\end{abstract}

Key words: Acer saccharum; earthworm invasion; ecosystem change; exotic species invasion extent; forest floor; Lumbricidae; northern hardwood forests; regional survey; roadless areas.

\section{INTRODUCTION}

The ecology of invasive soil organisms is poorly known, yet their effects on above- and belowground biota and ecosystem processes could be significant (Ehrenfeld and Scott 2001, Wardle et al. 2004). Studies have been limited to a few economically important nematodes, termites, ants, flatworms, and earthworms (Hendrix and Bohlen 2002). Even as the most studied soil organisms, earthworms (Darwin 1883, Edwards and Lofty 1972, Edwards and Bohlen 1996, Edwards 2004) were little known ecologically as invasive species until recently (Scheu and Parkinson 1994, Liu and Zou 2002, Bohlen et al. 2004a, Hale et al. 2005a). Recent research

Manuscript received 19 December 2005; revised 4 December 2006; accepted 12 December 2006; final version received 17 February 2007. Corresponding Editor: J. Gulledge.

3 Present address: Minnesota Department of Natural Resources, Office of Management and Budget Services, 500 Lafayette Road, Box 10, St. Paul, Minnesota 55155-4010 USA. E-mail: Andy.Holdsworth@dnr.state.mn.us has highlighted the effects of earthworm invasion on temperate and boreal forests previously devoid of earthworms, a region of North America covering several million square kilometers (Bohlen et al. 2004c, Frelich et al. 2006; Fig. 1). Earthworm invasion can significantly influence the distribution and retention of carbon, nitrogen, and phosphorous (Bohlen et al. 2004a, $b$, Suárez et al. 2004, Hale et al. 2005b), microbial biomass (Groffman et al. 2004), microfungal and microarthropod communities (McLean and Parkinson 1998, 2000, Migge 2001), fine root distributions (Fisk et al. 2004), and the diversity and abundance of herbaceous layer plants (Gundale 2002, Hale et al. 2006). The degree and character of these effects depends on land-use history and earthworm species (Bohlen et al. 2004a, $c$, Hale et al. 2005b) and likely on other factors such as climate, soils, and vegetation types that generally have strong influence on earthworm communities (Edwards and Bohlen 1996). The recent research suggests that invasive earthworms are important agents of change that will affect the composition, structure, and function of 
A

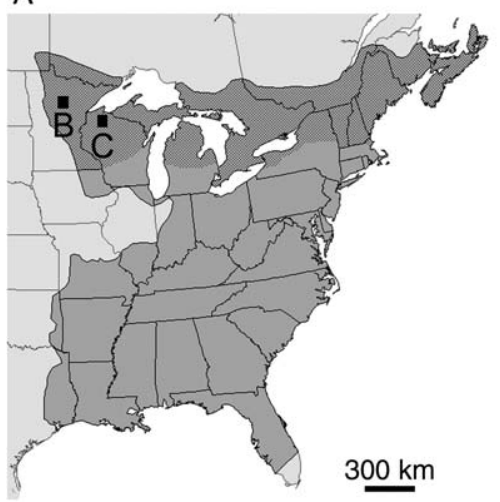

B

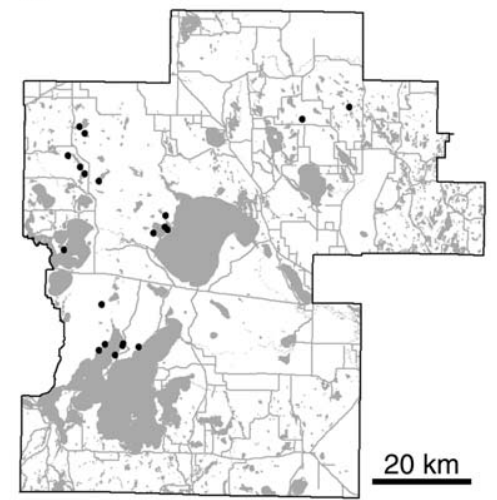

C

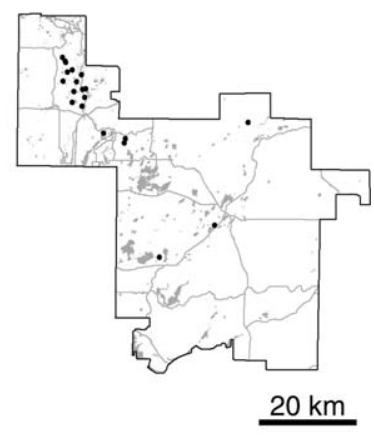

FIG. 1. Regional context of study and study sites. (A) Temperate broadleaf forest biome of eastern North America (medium gray) and approximate area that was previously devoid of earthworms (dark gray) (adapted from Hendrix and Bohlen [2002]). Forest stands sampled in (B) Chippewa National Forest, Minnesota, USA, and (C) Chequamegon National Forest, Wisconsin, USA.

northern temperate forests (Bohlen et al. 2004c) and are a significant conservation concern for many native plant species (Gundale 2002, Frelich et al. 2006, Hale et al. 2006).

Although there is increasing knowledge of the ecological effects of earthworm invasion, we know little about its extent. Researchers have described how largescale patterns of earthworm invasion in northeastern Europe relate to climatic patterns, habitat suitability, and human activity patterns (Tiunov et al. 2006). In western Michigan (USA), Gundale et al. (2005) estimated that $>90 \%$ of a sugar maple forest region is susceptible to earthworm invasion within 100 years. Otherwise, to our knowledge, there have been no regional studies of earthworm invasion. Surveys of earthworms at the county or political district level are absent for most states and provinces of North America (Reynolds 1995) and where they do exist are often sparse in coverage of different habitat types. Understanding the factors that influence the pattern and extent (i.e., invasion success) of different earthworm species in the northern temperate region is a clear research need (Bohlen et al. 2004a).

Predicting invasion success for individual species has proved difficult (Simberloff 1989, Williamson 1996, Mack et al. 2000). However, three general characteristics could be useful for first order assessments of exotic earthworm invasion success: habitat matching, past invasion success, and propagule pressure (Hendrix and Bohlen 2002). There is a suite of earthworms of the family Lumbricidae whose native habitats match many of those of northern temperate and boreal regions in North America previously devoid of earthworms. These species are generally successful invaders (Gates 1982, Reynolds 1995). These include Dendrobaena octaedra, Lumbricus rubellus, Lumbricus terrestris, and Aporrectodea caliginosa. Given this suite of species and their past invasion success, characterizing propagule pressure could aid predictions of the likely extent of future invasion.

Previous research suggests that earthworm propagule pressure is inversely related to distance from sites of earthworm introduction (Dymond et al. 1997). Thus, distance to potential introduction points could provide a first order surrogate of propagule pressure. Previously suggested sites of earthworm introduction include human settlements (Tiunov et al. 2006), agricultural clearings (Suárez et al. 2006), roads (Dymond et al. 1997, Gundale et al. 2005), and fishing areas where humans dumped bait worms (Alban and Berry 1994, Gundale et al. 2005, Tiunov et al. 2006). Given suitable habitat, we hypothesize that earthworm invasion would be spatially concentrated around these and other potential points of introduction in the western Great Lakes region of North America. If there is a spatial relationship with potential introduction points, it could provide the basis for a first order estimate of the extent of earthworm invasion in a particular habitat type and location.

The major questions that this study aims to answer are: (1) What is the extent and pattern of earthworm invasion in mature sugar maple-dominated forests of the western Great Lakes region of North America? (2) How does earthworm invasion relate to potential sites of earthworm introduction?

\section{Methods \\ Study regions}

This study included a total of 20 forest stands in each of the Chequamegon National Forest (CheqNF) in Wisconsin $\left(46^{\circ} 20^{\prime} \mathrm{N}, 91^{\circ} 16^{\prime} \mathrm{W}\right)$ and the Chippewa National Forest (ChipNF) in Minnesota $\left(47^{\circ} 25^{\prime} \mathrm{N}\right.$, $94^{\circ} 39^{\prime} \mathrm{W}$ ) (Fig. 1). The climate is humid, continental, and cold temperate with mean temperatures in January of $-12^{\circ}$ and $-15^{\circ} \mathrm{C}$ and in July of $19^{\circ}$ and $20^{\circ} \mathrm{C}$ and mean annual precipitation of 87 and $67 \mathrm{~cm}$ in the CheqNF and 
ChipNF, respectively (Midwestern Regional Climate Center 2005 [available online]). ${ }^{4}$ Both study regions predominantly occupy glacial till and outwash plains punctuated with hundreds of lakes. Soils are generally deep, well-drained fragiorthods and haplorthods in the CheqNF and deep, well-drained boralfs in the ChipNF (Albert 1995) that in the absence of earthworms are characterized by a thick forest floor composed of $\mathrm{O}_{\mathrm{i}}(\mathrm{L})$, $\mathrm{O}_{\mathrm{e}}(\mathrm{F})$, and $\mathrm{O}_{\mathrm{a}}(\mathrm{H})$ sub-horizons. Forest cover is mostly (85-89\%) hardwood forest with maple, aspen, and birch stands. The rest of the forest cover is coniferous consisting mostly of white pine, red pine, and jack pine. Both forests were logged in the late 19th and early 20th century, especially for white and red pine. While some areas were cleared as homesteads, most were soon abandoned in the 1920s and 1930s. Current land use includes forestry and recreation, predominantly fishing and boating from lakeshore cabins and resorts.

\section{Site selection and conditions}

Twenty forest stands of similar forest type, soils, and management history but varying likelihood of earthworm introduction were chosen in each national forest. We identified forest stands that met the following criteria: upland mesic hardwood forest type, $>60$ years old, on sandy-loam or loamy-sand soils, adjacent to lakes $>10$ acres, $>400 \mathrm{~m}$ in width from lake shore, and no logging activity in the last 40 years. Mature upland mesic hardwoods were chosen to complement the intensive studies in the same forest and soil types by Hale et al. (2005b). We made the a priori assumption that points of earthworm introduction would be concentrated near roads. Thus, we distinguished which candidate stands in each forest were $<500 \mathrm{~m}$ and which were $>500 \mathrm{~m}$ from a maintained road. Five hundred meters was chosen because it is the distance likely to be reached by earthworm invasion assuming the earliest likely introductions were 100 years ago and earthworm populations spread at $5 \mathrm{~m} / \mathrm{yr}$ (Marinissen and van den Bosch 1992).

Using recent $(>1990)$ aerial photographs, candidate stands were examined for canopy conditions and transect placement. Stands with significant canopy loss $(>50 \%)$ due to wind or other disturbance were eliminated because earthworm communities are affected by canopy gaps (Nachtergale et al. 2002). In the remaining stands, one transect was placed in each stand such that most transects were $>1000 \mathrm{~m}$ apart and approximately half the transects were $<500 \mathrm{~m}$ and half were $>500 \mathrm{~m}$ from a maintained road. In order to meet all other stand selection criteria, 11 of 40 transects had to be placed $500-1000 \mathrm{~m}$ from one other transect. The coordinates and bearing of each transect were measured on the aerial photo and used to site it in the field. Five to ten $($ median $=8)$ plots were spaced every $50 \mathrm{~m}$ along

\footnotetext{
${ }^{4}\langle$ http://mcc.sws.uiuc.edu/ $\rangle$
}

transects whose length ranged from 300 to $550 \mathrm{~m}$ (median, 400). Transect length varied based on the number of plots that could be sampled in 1-2 days. The statistical analysis accounted for the number of plots sampled per transect.

\section{Earthworm and habitat sampling}

Earthworms, soils, and vegetation were sampled at each plot, once in June or July of 2001 or 2002 in the CheqNF and August or September of 2001 or 2002 in the ChipNF. Earthworms were sampled using a combination of hand sifting, liquid mustard extraction, and $L$. terrestris midden counts. Sampling only occurred when soil moisture was sufficient for earthworm activity and when earthworms were active. Hand sifting (Bouché and Gardner 1984) occurred in a $0.12 \mathrm{~m}^{2}(35.4 \times 35.4$ $\mathrm{cm}) \times 30 \mathrm{~cm}$ deep subplot placed $1 \mathrm{~m}$ from the plot center. Liquid mustard extraction (Lawrence and Bowers 2002, Hale et al. 2005a) occurred in a $0.12-\mathrm{m}^{2}$ subplot, $2 \mathrm{~m}$ from the hand sift, on the opposite side of the plot center. L. terrestris middens (Nielson and Hole 1964) were counted in each $0.12-\mathrm{m}^{2}$ subplot as an additional measure of its presence/absence. When no middens were found in these two subplots we searched an additional two randomly chosen $0.12-\mathrm{m}^{2}$ subplots. All earthworms $(n=10316)$ were identified to species for adult specimens and to genus for juveniles using Reynolds (1977), Schwert (1990), and Sims and Gerard (1999) as taxonomic authorities. Length was measured to estimate ash-free dry biomass of each earthworm species using regression equations (Hale et al. 2004).

Vegetation and soil conditions that could influence earthworm populations were sampled at each plot (Table 1). All living trees $\geq 5 \mathrm{~cm}$ diameter-at-breastheight (dbh) and within a $314.2-\mathrm{m}^{2}$ plot area (i.e., $10 \mathrm{~m}$ radius of the plot center) were counted in $5-\mathrm{cm} \mathrm{dbh}$ classes. Percent canopy cover at the plot center was measured with a densiometer. Mineral soil samples were collected by horizon from the top $30 \mathrm{~cm}$ of a hand sifted earthworm plot at every third of each transect. Composite samples of equal proportions of each soil horizon were oven dried at $100^{\circ} \mathrm{C}$ for 48 hours and sifted through a no. $12(1.7 \mathrm{~mm})$ sieve. Soil texture was measured using the hydrometer method. A Corning 240 $\mathrm{pH}$ meter (Corning, Corning, New York, USA) was used to measure $\mathrm{pH}$ in deionized water.

\section{Distance measurements}

The location of each plot in the field was recorded using a Garmin GPS 12. As the accuracy of this unit is $\pm 15 \mathrm{~m}$ (Garmin, Olathe, Kansas, USA), plot coordinates were later corrected to conform to the inter-plot distances that were measured in the field using a laser range finder. ARC INFO (ESRI, Redlands, California, USA) was used to calculate the distance between each plot and the nearest occurrence of each of the following potential introduction sites: roads, trails, boat landings, cabins, campsites, lakeshores, and streams. Roads 
TABLE 1. Summary of habitat conditions and distances to potential sites of earthworm introduction for transects in the Chequamegon and Chippewa National Forests in Wisconsin and Minnesota, USA, respectively.

\begin{tabular}{|c|c|c|}
\hline Variable & $\begin{array}{l}\text { Chequamegon National Forest } \\
(n=20 \text { transects })\end{array}$ & $\begin{array}{c}\text { Chippewa National Forest } \\
(n=20 \text { transects })\end{array}$ \\
\hline \multicolumn{3}{|l|}{ Habitat variables $\uparrow$} \\
\hline Soil $\mathrm{pH} * * * *$ & $4.3 \pm 0.0$ & $5.5 \pm 0.1$ \\
\hline Sand $(\%)^{* *}$ & $66.7 \pm 3.6$ & $54.0 \pm 2.7$ \\
\hline Silt $(\%) * * *$ & $23.2 \pm 3.2$ & $36.9 \pm 2.4$ \\
\hline Clay $(\%)$ & $10.0 \pm 0.9$ & $9.1 \pm 0.5$ \\
\hline Maple-basswood basal area $\left(\mathrm{m}^{2} / \mathrm{ha}\right)^{* * \dagger}$ & $17.7 \pm 1.1$ & $23.0 \pm 1.4$ \\
\hline Total basal area $\left(\mathrm{m}^{2} / \mathrm{ha}\right)^{* *}$ & $32.5 \pm 0.8$ & $29.5 \pm 1.0$ \\
\hline Canopy openness (\%) & $3.7 \pm 0.0$ & $3.9 \pm 0.0$ \\
\hline \multicolumn{3}{|l|}{ Distance variables $(\mathrm{m}) \S$} \\
\hline Stream*** & $559(219-2000)$ & $2000(92-2000)$ \\
\hline Road & $346(54-1823)$ & $318(47-2552)$ \\
\hline Cabin** & $1755(400-2000)$ & $476(122-2000)$ \\
\hline Boat landing & $1934(246-2000)$ & $2000(294-2000)$ \\
\hline Trail** & $150(44-1400)$ & $2000(27-2000)$ \\
\hline Campsite & $1000(121-1000)$ & $\mathrm{NA} \uparrow$ \\
\hline
\end{tabular}

Note: Habitat variables are means $( \pm \mathrm{SE})$, and distance variables are medians (minimum-maximum).

$\dagger$ Soil pH, sand, silt, and clay are mean values of three soil plots for each of the 20 transects $(300-550 \mathrm{~m}$ in length). All other variables are means of all plots along transects. Sand, silt, and clay were arcsine square-root transformed and total basal area was $\log$-transformed for tests. Results of $t$ tests between forests for habitat variables: ${ }^{* *} P<0.01 ; * * * P<0.001 ; * * * * P<0.0001$.

$\$$ The combined basal area of the two major tree species with highest quality leaf litter for earthworms (based on highest Ca concentrations, cf. Reich et al. 2005): maple (Acer saccharum) and basswood (Tilia americana).

$\S$ Distance variables are based on the mean distance of transect plots to the nearest occurrence of the feature of interest. Results of Kruskall-Wallis tests for distance variables: ${ }^{* *} P<0.01$; $* * * P<0.001$.

T There were no campsites within $1000 \mathrm{~m}$ of Chippewa transects.

included constructed and maintained roads ranging from single lane dirt roads to multilane highways, but typically were two-lane dirt and paved roads. Trails include foot trails and old ( $>40$ years) logging skid trails. For sites that required digitizing (all but roads), all features within $2000 \mathrm{~m}$ of each plot were digitized, except for campsites that were measured up to $1000 \mathrm{~m}$ due to lack of additional data.

\section{Analyses}

Earthworm species with similar feeding and habitat preferences were combined into the same taxonomic groups used by Hale et al. (2005a, $b, 2006)$. We call these taxonomic groups not in a phylogenetic sense but rather as a means of classification. The "Dendrobaena" group includes Dendrobaena octaedra and D. rubida. These are small, pigmented epigeic species that inhabit and feed in the litter layer. D. rubida was only found in one plot so it was included in the "Dendrobaena" group. Juveniles of Lumbricus rubellus and L. terrestris are difficult to distinguish from each other so they were combined to form the "Lumbricus juveniles" group. Adult L. rubellus specimens were placed in their own group because of its greater capacity to mix the $\mathrm{O}_{a} / \mathrm{O}_{e}$ organic subhorizons into the upper mineral soil horizon (Gundale 2002). $L$. terrestris adults were placed in their own group because it is the only deep burrowing/litter feeding (anecic) species. The endogeic species Aporrectodea caliginosa (Sims and Gerard 1999) and A. rosea were placed into their own group. The other endogeic species, Octolasion tyrtaeum was placed in its own group because it often coexisted with Aporrectodea species but was much less common, occurring in only $10-15 \%$ of all forest transects in each national forest.

Analysis of earthworm presence is based on the combination of the hand sift, liquid extraction, and for L. terrestris, midden counts. Biomass of each taxonomic group was calculated as the mean biomass of the liquid extraction and hand sifting samples at each plot. The sampling efficiencies of these two sample methods vary by earthworm species (Lawrence and Bowers 2002). We took the mean of the two samples to capture the advantages of both methods while maximizing the sample area at each main plot. To maintain the many zero values and the original orders of magnitude in the earthworm biomass data, the following transformation was used: $b_{i j}=\log \left(x_{i j}+d\right)-c$ where $c$ is the integer of $\log _{10}[\min (x)], \min (x)$ is the lowest nonzero value of $x ; d$ is the inverse of $\log _{10}(c)$, and $b_{i j}$ is the log-transformed value (McCune and Grace 2002). Some samples (5\% and $8 \%$ in the CheqNF and ChipNF, respectively) were discarded due to inadequate preservation. Complementary field observations and our treatment of compromised samples minimized their impact on the results and conclusions (see Appendix A). Earthworm taxonomic group alpha, beta, and gamma diversity and community composition were analyzed using Sørensen's distance measure in PC-ORD (McCune and Mefford 1999, McCune and Grace 2002). Multi-response permutation procedures (MRPP; Mielke and Berry 2001) were used to compare the invasive earthworm communities found in the two national forests. Cluster and indicator species 


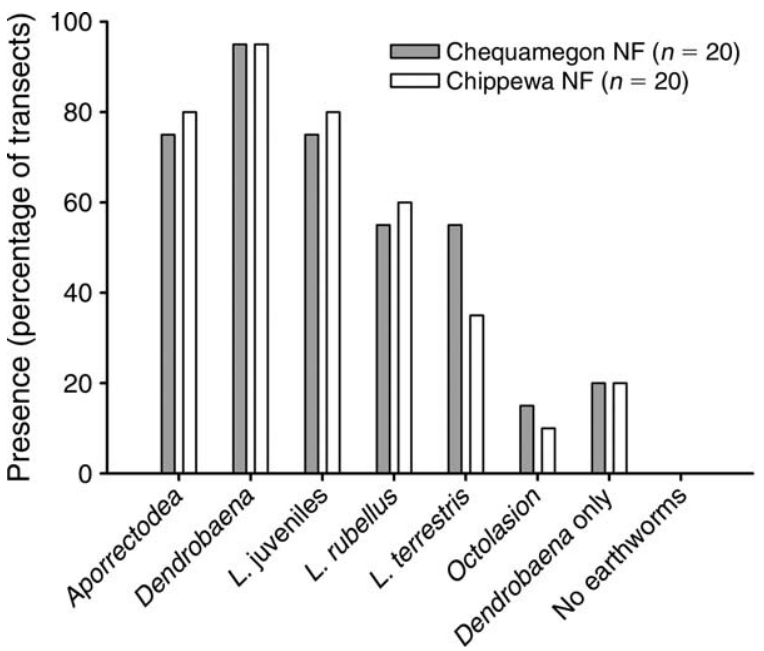

FIG. 2. Earthworm taxonomic groups present on 20 transects each in the Chequamegon and Chippewa National Forests (NF). Transects with Dendrobaena only are also shown.

analyses in PC-ORD were used to define earthworm species assemblages for each national forest and both forests combined. The resulting dendrograms were cut into major earthworm assemblages using Dufrêne and Legendre's (1997) method. This method calculates indicator values for each species in each assemblage based on relative abundance and frequency and tests for statistical significance using 1000 Monte Carlo randomizations (McCune and Grace 2002). Each dendrogram was cut at the number of assemblages where the average species $P$ value is minimized and where the number of significant $(P \leq 0.05)$ indicator species is maximized.

Habitat variables were compared between national forests and between earthworm assemblages within national forest using JMP (SAS Institute 2002). A random intercept logistic normal regression model was used to analyze the relationship between habitat and distance variables (Table 1) and the presence of each earthworm taxonomic group in the two national forests. Models for each earthworm taxonomic group in each forest were fit using SAS PROC NLMIXED (SAS 8.0; Wolfinger 1999) with a random effect on transect. Like standard logistic normal regression models, this model uses a logit link function for the response, the count of plots with earthworm group present along each transect, that is assumed to follow a binomial distribution. Interpretation of regression coefficient estimates also follows that of standard logistic regression (e.g., the transformed regression coefficient estimate, $\exp \left(\right.$ Estimate $\left._{\mathrm{RD}}\right)$, is the multiplicative change in odds of earthworm occurrence for each $1-\mathrm{m}$ change in distance to the nearest road; see Agresti 1996). By using a random intercept for each transect the model not only accounts for correlation between observations (see Appendix A) within each transect but also permits the application of results to the larger sample population of transects (Littell et al. 1996; also see
Engeman et al. 2003, Blackburn et al. 2004). The transect mean of the habitat and distance variables were used as predictors. Starting models and parameters for PROC NLMIXED were selected using backward elimination on all habitat and distance variables (Table 1) using PROC LOGISTIC (SAS 8.0). Initial models also included potential interactions supported by interaction plots. Model selection in PROC NLMIXED used comparisons of model BIC (Bayesian information criterion) and plots of predicted vs. observed values.

See Appendix A for additional analytical details.

\section{Results \\ Habitat conditions and the extent and pattern of earthworm invasion}

Earthworm invasion was extensive but incomplete in the 40 transects of the two national forests. The extent of invasion varied with earthworm taxonomic group but was similar between the two national forests (Fig. 2). Four of the six groups were found in a majority of transects in both national forests. These included Dendrobaena (95\%), Aporrectodea (75-80\%), L. juveniles (75-80\%), and L. rubellus (55-60\%; Fig. 2). L. terrestris was found in 55\% of CheqNF transects but in only $35 \%$ of ChipNF transects. Octolasion was uncommon (10$15 \%$ of transects). Twenty percent of transects had only Dendrobaena present (Fig. 2). While there were no earthworm-free transects in either national forest, $18 \%$ of CheqNF and $4 \%$ of ChipNF plot samples produced zero earthworms.

The composition and diversity of earthworm taxonomic groups were also similar between the two national forests. Gamma diversity (total number of taxonomic groups sampled) was six and six, alpha diversity (mean number of taxonomic groups found in plots) was 3.8 and 3.6 taxonomic groups per transect, and beta diversity (gamma/alpha) was 1.6 and 1.7 for the CheqNF and ChipNF, respectively. Based on MRPP, there was no statistically significant difference between national forests in transect earthworm species composition based on ash-free dry mass (AFDM) nor presence/absence data (AFDM, average Sørensen's distance, 0.38 and 0.40 for the CheqNF and ChipNF, respectively, $A$ statistic $=$ $-0.013, P=0.73$; presence/absence, average Sørensen's distance, 0.30 and 0.29 for the CheqNF and ChipNF, respectively, $A$ statistic $=-0.007, P=0.47, N=39$ ).

Cluster and indicator species analyses identified two earthworm assemblages in the two national forests. The most common assemblage in the CheqNF was best indicated (indicator values $\geq 50 \%$ ) by $L$. juveniles and Aporrectodea (Appendix B: Table B1, Fig. B3). This assemblage occupied $78 \%$ of the 123 plots with earthworms in that forest. The Dendrobaena assemblage was indicated by Dendrobaena alone and represented $22 \%$ of plots with earthworms. Earthworm communities in the ChipNF divided into two assemblages (Appendix B: Table B1, Fig. B4). As in the two assemblage grouping for the CheqNF there was a Lumbricus- 
TABLE 2. Logistic normal model estimates and $t$ test results for earthworm taxonomic groups and assemblages for the Chequamegon National Forest.

\begin{tabular}{|c|c|c|c|c|c|c|c|c|c|c|c|c|}
\hline \multirow[b]{2}{*}{ Earthworm species } & \multicolumn{4}{|c|}{ Intercept } & \multicolumn{4}{|c|}{ Road distance } & \multicolumn{4}{|c|}{$\sigma^{2} u^{\dagger}$} \\
\hline & Estimate & $\mathrm{SE}$ & $t$ & $P$ & Estimate & SE & $t$ & $P$ & Estimate & $\mathrm{SE}$ & $t$ & $p$ \\
\hline \multicolumn{13}{|l|}{ Taxonomic group } \\
\hline L. rubellus & -0.04 & 0.39 & -0.11 & 0.911 & -0.003 & 0.001 & -3.25 & 0.004 & 0.43 & 0.56 & 0.77 & 0.453 \\
\hline L. juveniles & 8.13 & 3.31 & 2.45 & 0.024 & -0.009 & 0.003 & -2.67 & 0.015 & 11.95 & 9.55 & 1.25 & 0.226 \\
\hline L. terrestris & 1.96 & 0.87 & 2.25 & 0.036 & -0.004 & 0.001 & -3.22 & 0.005 & 4.30 & 2.74 & 1.57 & 0.133 \\
\hline Aporrectodea & 4.89 & 1.38 & 3.54 & 0.002 & -0.006 & 0.002 & -3.68 & 0.002 & 5.46 & 3.89 & 1.40 & 0.176 \\
\hline Dendrobaena & 0.52 & 0.38 & 1.37 & 0.186 & $\cdots$ & $\cdots$ & $\cdots$ & $\cdots$ & 1.89 & 1.02 & 1.86 & 0.079 \\
\hline \multicolumn{13}{|l|}{ Assemblage $\ddagger$} \\
\hline Lumbricus-Aporrectodea & 8.32 & 3.62 & 2.30 & 0.033 & -0.009 & 0.004 & -2.49 & 0.022 & 13.11 & 10.86 & 1.21 & 0.242 \\
\hline Dendrobaena & -6.18 & 2.24 & -2.77 & 0.012 & 0.004 & 0.002 & 2.16 & 0.044 & 7.72 & 5.33 & 1.45 & 0.163 \\
\hline
\end{tabular}

Notes: For all models, $\mathrm{df}=19$. Ellipses denote that the predictor was removed because it did not improve model fit significantly based on $\triangle \mathrm{BIC}$ (Bayesian information criterion).

$\dagger$ The variance of the random intercept for transect.

\$ The Lumbricus-Aporrectodea assemblage consists of plots dominated by L. juveniles, Aporrectodea, and Lumbricus rubellus. The Dendrobaena group consists of plots dominated by Dendrobaena octaedra.

Aporrectodea assemblage (62\% of plots with earthworms) and a Dendrobaena assemblage (38\% of plots with earthworms). The combined data for the two national forests also identified the same two assemblages (see Appendix B: Table B1).

Habitat conditions for the two assemblages differed significantly in the CheqNF but not in the ChipNF (see Appendix B: Table B2). In comparison to the habitat conditions of the Dendrobaena assemblage in the CheqNF, the Lumbricus-Aporrectodea assemblage occurred in plots that had significantly (Tukey's hsd, $P<$ $0.05)$ less sand $(60 \%$ vs. $80 \%)$ and significantly more silt ( $28 \%$ vs. $13 \%$ ), clay ( $12 \%$ vs. $7 \%$ ), and maple-basswood basal area (19\% vs. 12\%). Habitat conditions of the Dendrobaena assemblage were similar to those of earthworm free plots except for maple-basswood basal area, which was comparable to that of LumbricusAporrectodea plots.

\section{Earthworm invasion and potential introduction sites}

The proximity of transects to several potential earthworm introduction sites differed between the national forests. CheqNF transects were significantly closer to streams and trails (medians, $559 \mathrm{~m}$ and $150 \mathrm{vs.}$ $2000 \mathrm{~m}$, respectively) while ChipNF transects were significantly closer to cabins (median, 476 vs. $1755 \mathrm{~m}$ ) (Table 1). However, distance to roads $(318-346 \mathrm{~m})$ and boat landings (median, 1934-2000 m) were similar in the two forests (Table 1).

Of all the habitat and distance variables in the CheqNF, distance to roads was the only significant predictor of presence of all but one earthworm taxonomic group and both earthworm assemblages (Table 2, Appendix B: Fig. B1). There was a significant negative relationship between the distance to the nearest road and the presence of four taxonomic groups (Aporrectodea, L. juveniles, L. rubellus, L. terrestris) and the $L$. juveniles-Aporrectodea assemblage (Table 2). For each additional $100 \mathrm{~m}$ traveled away from a road, the odds of finding these groups decreased 0.3-0.9 times. There were no significant predictors of the Dendrobaena taxonomic group. However, the odds of encountering the Dendrobaena assemblage (usually plots with Dendrobaena only) instead increased by 0.4 times with each additional $100 \mathrm{~m}$ traveled away from the nearest road.

Model selection for L. terrestris also resulted in an alternative model to the road only model. This alternative included a positive relationship of $L$. terrestris occurrence to campsite and trail distance and a negative relationship to boat landing and stream distance. However, plots of the predicted values vs. the observed values revealed that this more complicated model was not noticeably different from the road only model. The L. terrestris road only model is used for the subsequent analysis to facilitate direct comparison to the other earthworms groups that were best predicted with the road only model.

The major predictor of earthworm presence in the ChipNF was distance to cabins. The Aporrectodea and L. juveniles taxonomic groups and the LumbricusAporrectodea assemblage had a significantly $(P<0.05)$ negative relationship to cabin distance (Table 3; Appendix B: Fig. B2). For each additional $100 \mathrm{~m}$ traveled away from a cabin, the odds of finding these groups and assemblage decreased $0.4-0.8$ times. The best model found by minimizing BIC (Bayesian information criterion) for Aporrectodea also included proportion of clay in the soil. As distance from the nearest cabin increased, the probability of finding Aporrectodea decreased and as clay content increased the probability increased (Table 3). L. terrestris also had a negative relationship with cabin distance but this relationship was only marginally significant $(P=0.079)$. As in the CheqNF there were no significant predictors of Dendrobaena. However, unlike in the CheqNF, there were no significant predictors for the L. rubellus taxonomic group and the Dendrobaena assemblage (Table 3). 
TABLE 3. Logistic normal model estimates and $t$ test results for earthworm taxonomic groups and assemblages for the Chippewa National Forest.

\begin{tabular}{|c|c|c|c|c|c|c|c|c|c|c|c|c|}
\hline \multirow[b]{2}{*}{ Earthworm species } & \multicolumn{4}{|c|}{ Intercept } & \multicolumn{4}{|c|}{ Cabin distance } & \multicolumn{4}{|c|}{ Clay } \\
\hline & Estimate & SE & $t$ & $P$ & Estimate & SE & $t$ & $P$ & Estimate & $\mathrm{SE}$ & $t$ & $P$ \\
\hline \multicolumn{13}{|l|}{ Taxonomic group } \\
\hline L. rubellus & -1.51 & 0.86 & -1.77 & 0.093 & $\ldots$ & $\ldots$ & $\cdots$ & $\ldots$ & $\cdots$ & $\cdots$ & $\cdots$ & $\cdots$ \\
\hline L. juveniles & 4.21 & 1.83 & 2.30 & 0.033 & -0.004 & 0.002 & -2.16 & 0.044 & $\cdots$ & $\cdots$ & $\cdots$ & $\cdots$ \\
\hline L. terrestris & -0.17 & 1.71 & -0.10 & 0.92 & -0.004 & 0.002 & -1.85 & 0.079 & $\cdots$ & $\cdots$ & $\cdots$ & $\ldots$ \\
\hline Aporrectodea & -14.81 & 7.65 & -1.93 & 0.068 & -0.008 & 0.003 & -2.45 & 0.024 & 261.92 & 117.9 & 2.22 & 0.039 \\
\hline Dendrobaena & 2.77 & 0.98 & 2.81 & 0.011 & $\cdots$ & $\cdots$ & $\cdots$ & $\cdots$ & $\cdots$ & $\cdots$ & $\cdots$ & $\cdots$ \\
\hline \multicolumn{13}{|l|}{ Assemblage $\ddagger$} \\
\hline Lumbricus-Aporrectodea & 4.18 & 1.82 & 2.30 & 0.033 & -0.003 & 0.002 & -2.11 & 0.048 & $\ldots$ & $\ldots$ & $\ldots$ & $\cdots$ \\
\hline Dendrobaena & -2.02 & 1.27 & -1.59 & 0.128 & $\cdots$ & & $\cdots$ & $\cdots$ & $\cdots$ & $\cdots$ & $\cdots$ & $\cdots$ \\
\hline
\end{tabular}

Notes: For all models, $\mathrm{df}=19$. Ellipses denote that the predictor was removed because it did not improve model fit significantly based on $\triangle \mathrm{BIC}$ (Bayesian information criterion).

$\dagger$ The variance of the random intercept for transect.

\$ The Lumbricus-Aporrectodea assemblage consists of plots dominated by L. juveniles, Aporrectodea, and Lumbricus rubellus. The Dendrobaena group consists of plots dominated by Dendrobaena octaedra.

The precision of model predictions varied among transects. The width of 95\% confidence intervals for predicted probability values ranged from 0.00 to 1.14 in both forests. The proportion of transects with low precision (width of confidence intervals $>0.25$ ) of predicted probability values was greatest for $L$. rubellus and L. terrestris in the CheqNF. Sixty-five percent of transects had low precision for these taxonomic groups in contrast to $25 \%$ for $L$. juveniles and the LumbricusAporrectodea assemblage.

Earthworm taxonomic groups have different extents of invasion away from roads in the CheqNF and from cabins in the ChipNF (Fig. 3). We used the logistic normal model parameters to calculate predicted probability of occurrence curves relative to road distance for each earthworm taxonomic group. At the transect level the order of invasion extent is $L$. juveniles $>$ Aporrectodea $>$ L. terrestris $>$ L. rubellus (Fig. 3A). Probability of finding each taxonomic group does not cross below $50 \%$ until 930, 830, and $470 \mathrm{~m}$ for $L$. juveniles, Aporrectodea, and $L$. terrestris groups, respectively. For all taxonomic groups, the probability of occurrence does not decline to $5 \%$ until the nearest road is at least $1300 \mathrm{~m}$ away. In contrast, the probability of finding Dendrobaena alone increases as the distance to nearest road increases, crossing $50 \%$ at $1540 \mathrm{~m}$. As the $L$. juveniles-Aporrectodea assemblage is dominated by $L$. juveniles, its parameter values are nearly identical to those of $L$. juveniles (Table 2).

The pattern of earthworm invasion across transects (Fig. 3) reflects the pattern observed within transects (Fig. 4). Within some transects of the region there are leading edges of invasion (sensu Hale et al. 2005a) where earthworm invasion is incomplete but appears to be progressing through the transect. Three of the CheqNF transects and five of the ChipNF transects crossed a leading edge where $L$. juveniles, Aporrectodea, or $L$. terrestris taxonomic groups were present in one-third to one-half of the plots at the lakeshore end of the transect
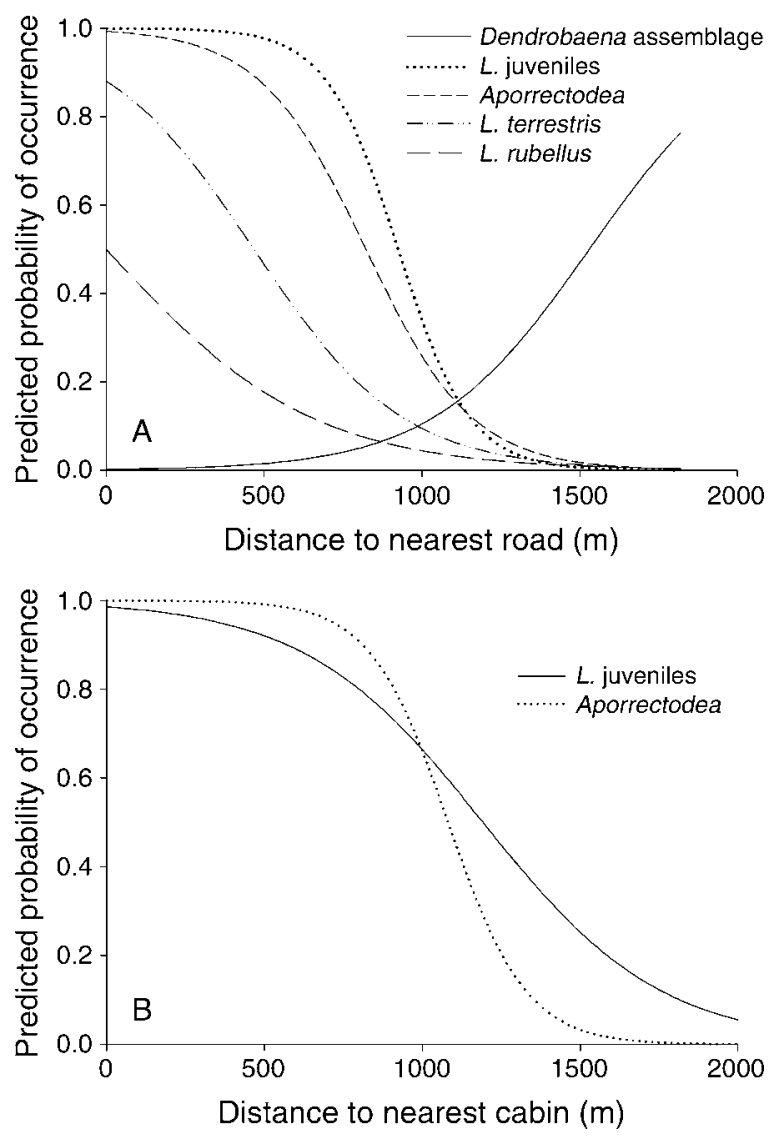

FIG. 3. Predicted probability of occurrence of the four major earthworm taxonomic groups and the Dendrobaenadominated assemblage in relation to (A) distance to nearest road in the Chequamegon National Forest and (B) distance to nearest cabin in the Chippewa National Forest. Predicted probabilities are based on the logistic normal models summarized in Tables 2 and 3 for the respective forests. The Lumbricus-Aporrectodea assemblage is excluded because it is nearly identical to the $L$. juveniles model. 
TABLE 3. Extended.

\begin{tabular}{lrcc}
\hline \hline \multicolumn{3}{c}{$\sigma^{2} u^{\dagger}$} \\
\hline Estimate & $\mathrm{SE}$ & $t$ & $p$ \\
\hline & & & \\
10.26 & 5.72 & 1.79 & 0.089 \\
15.98 & 9.70 & 1.65 & 0.12 \\
18.47 & 12.78 & 1.45 & 0.165 \\
6.57 & 4.54 & 1.45 & 0.164 \\
10.43 & 6.31 & 1.65 & 0.115 \\
& & & \\
15.61 & 9.52 & 1.64 & 0.118 \\
21.61 & 13.46 & 1.61 & 0.125 \\
\hline
\end{tabular}

but absent in one-third to one-half of the plots at the other end. In the CheqNF leading edge transects, Dendrobaena alone was found $>200 \mathrm{~m}$ from where $L$. juveniles and Aporrectodea occurred, and L. terrestris occurred just behind L. juveniles and Aporrectodea (Fig. 4A). In the ChipNF leading edge transects the distinction between Dendrobaena and the other taxonomic groups is not as great, but the relative order of Dendrobaena $>L$. juveniles $>$ Aporrectodea $>L$. terrestris still holds (Fig. 4B). As in Hale et al. (2005a) there were no differences in measured soil and vegetation variables found to explain the leading edge pattern.

\section{Estimated extent of invasion in hardwood stands of the Chequamegon National Forest}

To make the first estimate of extent of earthworm invasion in a particular northern hardwood forest region, the logistic normal model results were applied to all sandy loam and loamy sand soils of the CheqNF. The forest was divided into a grid of $400 \times 400 \mathrm{~m}$ cells to match the transect scale on which the model was based. For each cell the distance to the nearest road was measured and the probability of occurrence of the Lumbricus-Aporrectodea assemblage calculated based on the parameter estimates in Table 2. For the cells occupying upland mesic hardwoods within $500 \mathrm{~m}$ of a lakeshore $(n=626), 82 \%$ were highly likely $(91-100 \%$ chance) and only $3 \%$ were unlikely (0-10\% chance) to have Lumbricus-Aporrectodea present. The percentages were similar regardless of whether all upland mesic hardwood cells $(n=3267)$ were considered or only ones within $100 \mathrm{~m}$ of a lakeshore $(n=97)$. We could not perform this estimate in the ChipNF because it has no GIS coverage of cabin locations.

\section{Discussion}

This regional survey of 40 mature maple-dominated forest stands revealed that earthworm invasion is advanced but incomplete in two national forests of the western Great Lakes region. The earthworm assemblages and the pattern of their invasion were remarkably similar for the two national forests separated by $300 \mathrm{~km}$, and to the sketchy patterns available from the more spatially limited prior studies in northern temperate forests. This similarity presents the opportunity to discuss factors driving patterns of earthworm invasion in the western Great Lakes region. It also suggests that the patterns of invasion observed in this study can be generalized to the larger population of mature mesic upland hardwood forests of the region to permit a first order estimate of the extent of earthworm invasion in hardwood forests previously devoid of earthworms.

\section{Common invasive earthworm assemblages}

There were only two major earthworm assemblages found and they were the same in both national forests. The Dendrobaena assemblage was identified by Dendrobaena octaedra alone and was generally found in the most remote areas. The Lumbricus-Aporrectodea assemblage was identified by those two genera and by adult $L$. rubellus and L. terrestris and occasionally by Octolasion tyrtaeum. These two assemblages correspond to two of the four assemblages found in the intensive four-year study of leading edges of earthworm invasion by Hale et al. (2005a) in the ChipNF. The Dendrobaena assemblage corresponds to the earthworm community in the earliest

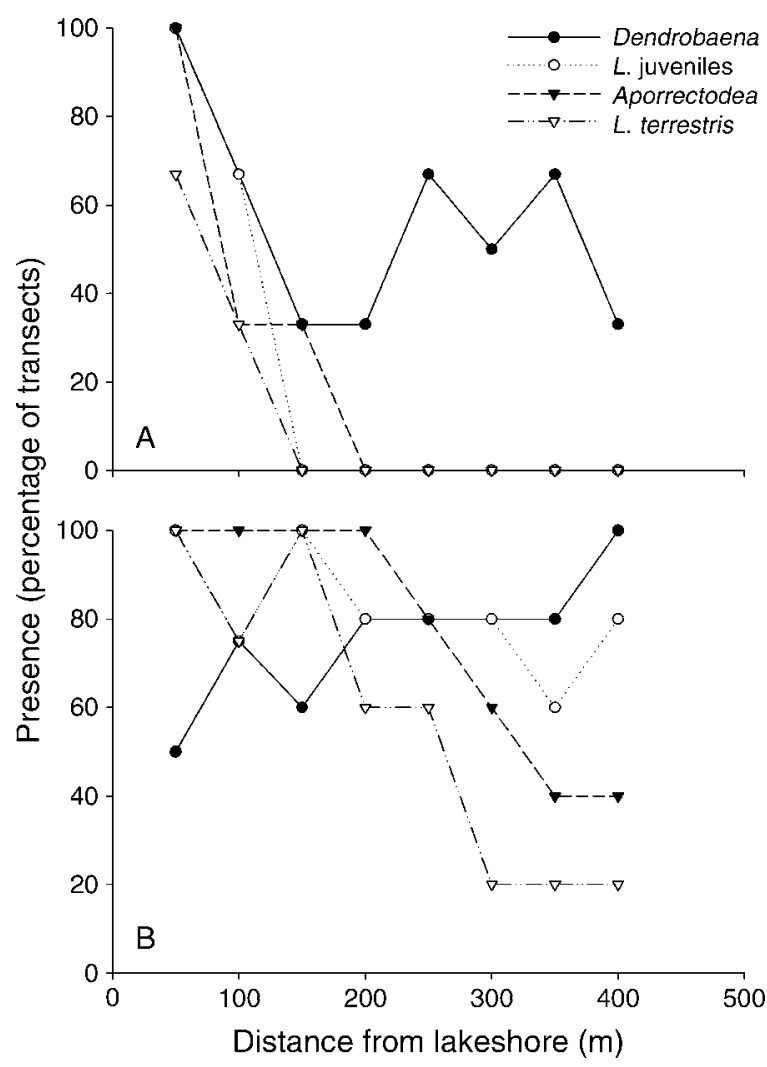

FIG. 4. Occurrence of the four major earthworm taxonomic groups within transects that are incompletely invaded (i.e., where L. juveniles, Aporrectodea, or L. terrestris were present in one-third to one-half of plots at one end of the transect but absent in one-third to one-half in the second half) in (A) the Chequamegon National Forest $(n=3$ transects) and (B) the Chippewa National Forest ( $n=5$ transects). 
stage of invasion of the Hale et al. study and the Lumbricus-Aporrectodea assemblage corresponds to the assemblage found in the part of the stand invaded longest ago. The Lumbricus-Aporrectodea assemblage is also similar to earthworm associations in temperate forests in Europe (Edwards and Bohlen 1996), the western Great Lakes (Morgenweck and Marshall 1982, Alban and Berry 1994, Gundale et al. 2005), and the northeastern United States (Shakir and Dindal 1997, Bohlen et al. 2004a).

\section{Sequence of species invasion}

The frequency of occurrence of earthworm taxonomic groups at the regional scale reflects the sequence of earthworm species invasions at the stand scale. The order of species occurrence frequency across transects was Dendrobaena $>$ Aporrectodea $=L$. juveniles $>L$. rubellus $>$ L. terrestris for both national forests (Fig. 2). This order was also generally found in the eight transects with leading edges of invasion in both national forests (Fig. 4) and is similar to the sequence of invasion documented by Hale et al. (2005a) and Tiunov et al. (2006).

The sequence of invasion can be explained largely by differences in species traits such as reproductive strategy, fecundity, cold tolerance, niche type, and colonization rates. The widespread Dendrobaena octaedra is parthenogenetic, has high cocoon (egg mass) production (Dymond et al. 1997), and high cocoon cold tolerance (Holmstrup et al. 1990), and inhabits and feeds in leaf litter, which is especially abundant in earthworm-free forests. The next most widespread species, L. rubellus (and its juveniles), is also a litter dwelling species and has relatively high cocoon production (106 cocoons per worm per year; Wilcke 1952) and high colonization rates (14 m/yr; Marinissen and van den Bosch 1992). The major species found with or just behind L. rubellus, i.e., Aporrectodea caliginosa, has moderate fecundity (27 cocoons per worm per year) and lower colonization rates (7-9 m/yr; Marinissen and van den Bosch 1992). In contrast, the species most widely used as fishing bait but relatively limited in distribution, L. terrestris, has low cocoon production (Butt and Nuutinen 1998) and low colonization rates $(4 \mathrm{~m} / \mathrm{yr}$; Marinissen and van den Bosch 1992). Although the cocoon production data are mostly from laboratory studies, they demonstrate relative patterns. The colonization rate data are from field studies in a variety of European habitats, and the relative rates are comparable to those found by Dunger (1989) and in northern Minnesota by Hale et al. (2005a).

\section{Earthworm invasion and propagule pressure}

The location where the sequence of invasion previously described occurs is related to surrogates of propagule pressure. In the CheqNF, proximity to roads was the only significant predictor of presence of both earthworm assemblages and all but one earthworm taxonomic group (Table 2). The increasing probability of finding the Dendrobaena assemblage (usually plots with Dendrobaena only) as distance to the nearest road increases (Fig. 3A) in contrast to the decreasing probability for the four earthworm taxonomic groups, underscores the relative success Dendrobaena species have in colonizing the landscape. The association with roads has also been found for many plant invasions (e.g., Tyser and Worley 1992, Parendes and Jones 2000, Watkins et al. 2003). Associated with a broad range of human activities, roads are a general predictor of earthworm invasion across a relatively large $(>1000$ m) spatial scale. As cabins, boat landings, and other potential sites of earthworm introduction are usually served by roads, their individual contributions to earthworm invasion are confounded with roads. Far from roads, the variety of likely introduction points is limited to wilderness campsites and other remote human activity centers. In a finer-scale study where most sample points were $<1000 \mathrm{~m}$ from a road, roads were not a significant predictor of earthworm invasion while agricultural clearings and wet soils were (Suárez et al. 2006). In summary, road presence is most appropriate as a coarse-scale predictor of earthworm invasion.

Instead of proximity to roads, cabin proximity was the most significant predictor of the $L$. juveniles and Aporrectodea groups and their related assemblage in the ChipNF (Table 3). This difference is likely due to physiographic differences between the two national forests. Unlike the CheqNF, the ChipNF study region has several very large lakes $\left(>200 \mathrm{~km}^{2}\right)$ with mature hardwood stands along their shores (Fig. 1). The large lakes permit boat access to hardwood forest stands and the cabins that are $>2 \mathrm{~km}$ from roads.

The low precision of model predictions and lack of statistically significant relationships could be due to other factors that might influence invasion success. In many cases, poor model precision can be partially explained by site-specific conditions such as earthworm invasion from a remote lakeside campsite. Forest stands adjacent to study sites subjected to logging activity (Gundale et al. 2005) and differences in local land-use histories (Kalisz and Dotson 1989) may be uncharacterized sources of invasion. Even with maps of a fuller range of potential introduction sites and an expanded survey of earthworms, stand-level prediction of earthworm invasion will likely be limited in precision due to local variation in probability of species introduction, establishment and spread, and variation in time since introduction.

\section{Current and potential extent of earthworm invasion}

The current distribution of earthworm invasion in the two national forests is extensive but incomplete. $L$. juveniles and Aporrectodea species were found in 75$80 \%$ of transects in both forests and L. terrestris adults and Octolasion in fewer transects (Fig. 2). The invasion of the Lumbricus-Aporrectodea assemblage generally extends nearly $1200 \mathrm{~m}$ from roads in the CheqNF 
leaving the largest $(>1600$ ha) roadless areas mostly uninvaded except for small invasions extending $<200 \mathrm{~m}$ from remote campsites (Fig. 5). In contrast, invasion by Dendrobaena octaedra was almost complete, being found in 95\% of all transects in both national forests (Fig. 2).

Gundale et al. (2005) estimated that $92-99 \%$ of hardwood forest in another western Great Lakes national forest is susceptible to earthworm invasion within the next 100 years. Given the lack of clear habitat constraints on the current extent of earthworm invasion, we also expect earthworm invasion to progress through a majority of upland mesic hardwood stands in the region. However, stands surrounded by acidic wetlands with a $\mathrm{pH}$ below that tolerated by earthworms (Edwards and Bohlen 1996) are less likely to be invaded. Several transects in the ChipNF were relatively close to cabins yet uninvaded by Lumbricus-Aporrectodea, perhaps due to being surrounded by acidic wetlands. Shallow soils over bedrock, a shallow pan layer, or coarse-textured soils will likely prevent the local invasion of deep burrowing $L$. terrestris. The rates at which upland mesic hardwood forests will be invaded will depend on such factors as frequency and distribution of additional introductions, edaphic conditions, climate, and landscape habitat configuration.

\section{Implications for ecosystem processes and forest management and conservation}

Earthworm invasion has increased spatial heterogeneity in the landscape with important ecosystem and conservation consequences. In the minority of the landscape where only Dendrobaena has invaded sugar maple-dominated forest, the impact of invasion is relatively minor; the forest floor consists of welldeveloped $\mathrm{O}_{i}, \mathrm{O}_{\mathrm{e}}$, and $\mathrm{O}_{a}$ sub-horizons over distinct mineral soil horizons and exhibits negligible impact on understory plant species richness and community composition (Hale et al. 2005b, 2006). In contrast, the majority of the landscape invaded by the LumbricusApporectodea assemblage has likely been notably altered. Also working in the ChipNF study region, Hale et al. $(2005 b, 2006)$ found that Lumbricus-Aporrectodeainvaded areas in north central Minnesota were transformed to a mull humus form with very thin $\mathrm{O}_{e} / \mathrm{O}_{\mathrm{a}}$ subhorizons, increased soil bulk density, reduced nitrate, ammonium, and phosphate availability, and significantly reduced richness and abundance of plant species in comparison to Dendrobaena-invaded areas. They also were linked to the local extirpation of a threatened plant species, Botrychium mormo (Gundale 2002). In intensive studies of earthworm invasion in a relatively undisturbed forest of New York state, Bohlen et al. (2004a) found that invasion by a comparable community to the Lumbricus-Aporrectodea assemblage resulted in reduced upper soil $\mathrm{C}$ storage, reduced $\mathrm{C}: \mathrm{N}$ ratios, and altered distribution and function of fine roots and microbes. Although understanding the mechanisms of these community and ecosystem changes will require more
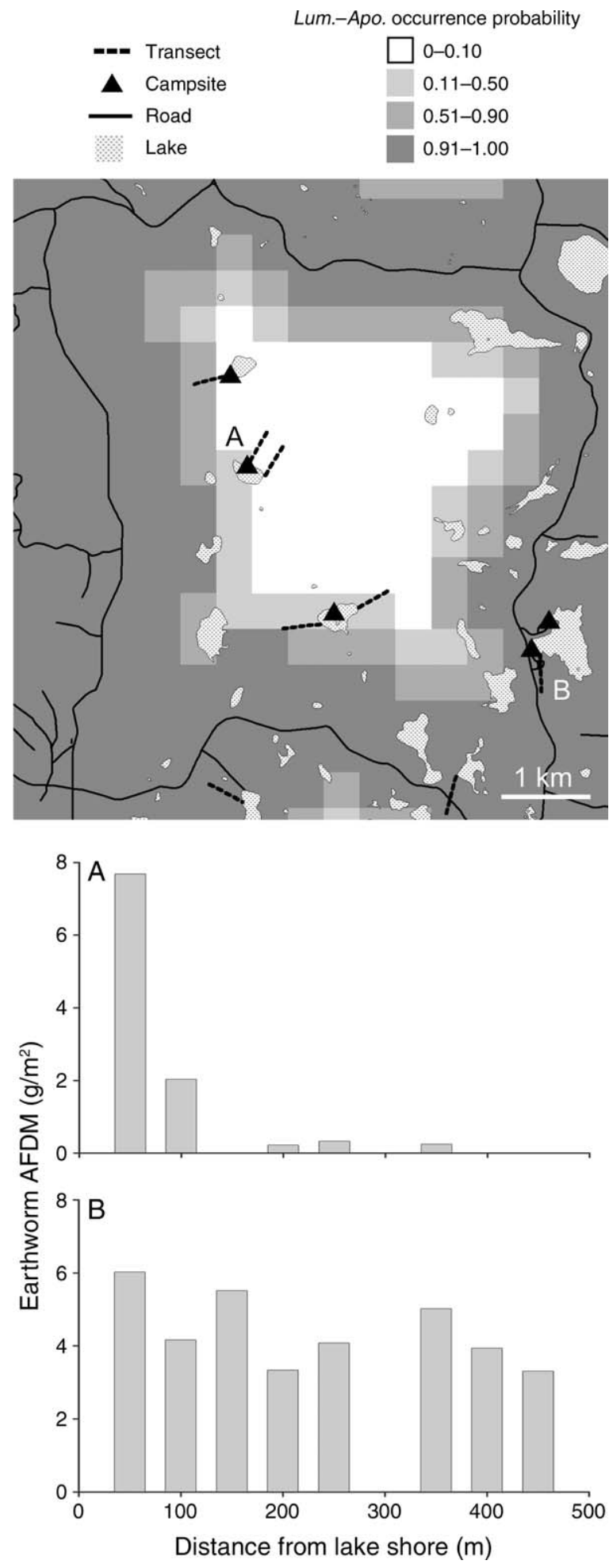

FIG. 5. Probability map of Lumbricus-Aporrectodea (Lum.Apo.) invasion in a $45-\mathrm{km}^{2}$ hardwood-dominated area of the Chequamegon National Forest. The histograms show measured earthworm ash-free dry mass (AFDM) along two transects in areas modeled as (A) low-medium probability of occurrence in the Rainbow Lake Wilderness Area and (B) high probability of occurrence outside the wilderness area. 
research, earthworm community composition appears to play a major role (Bohlen et al. 2004a, Suárez et al. 2004, Hale et al. 2005b, 2006).

Given the significant changes caused by earthworm invasion, the degree of earthworm invasion is an important factor that should be assessed in forest stand and ecosystem evaluations (Bohlen et al. 2004a). From this study we estimate that $\sim 80 \%$ of the upland mesic hardwood landscape is likely in the earthworm-impacted state described in recent studies. However, determining the actual status of invasion will require stand-level assessments. Such assessments can identify where earthworm invasion is a factor so that forest managers can better understand current and potential future forest conditions. Just as importantly they will identify areas uninvaded by Lumbricus-Aporrectodea. Given that eradication of earthworms is unlikely to be feasible (Hendrix and Bohlen 2002), these areas could serve as important refugia for plant species that are significantly impacted by earthworms. The identification of these areas would also help target existing educational campaigns designed to prevent people from dumping their unused fishing bait in these refugia.

\section{ACKNOWLedgments}

This research was supported by the National Science Foundation (DEB-0075236), the Minnesota Department of Natural Resources, the Wilderness Research Foundation, a University of Minnesota Wood-Rill Fellowship, and a UMN Doctoral Dissertation Fellowship. We thank V. Hendrycks, S. Wokson, B. Boyce, N. Worm, S. Schmidt, J. Yahnke, C. Mueller, D. Martin, and staff at the Chequamegon and Chippewa National Forests for assistance with field and laboratory work. C. Hale provided valuable advice throughout the work. R. Kirk assisted greatly with the GIS analysis. Sarah E. Hobbie, Paul F. Hendrix, Galin Jones, and four anonymous reviewers provided valuable comments on the manuscript.

\section{Literature Cited}

Agresti, A. 1996. An introduction to categorical data analysis. Wiley, New York, New York, USA.

Alban, D. H., and E. C. Berry. 1994. Effects of earthworm invasion on morphology, carbon, and nitrogen of a forest soil. Applied Soil Ecology 1:243-249.

Albert, D. A. 1995. Regional landscape ecosystems of Michigan, Minnesota, and Wisconsin: a working map and classification. USDA Forest Service General Technical Report NC-178. North Central Forest Experiment Station, Saint Paul, Minnesota, USA.

Blackburn, T. M., P. Cassey, R. P. Duncan, K. L. Evans, and K. J. Gaston. 2004. Avian extinction and mammalian introductions on oceanic islands. Science 305:1955-1958.

Bohlen, P. J., P. M. Groffman, T. J. Fahey, M. C. Fisk, E. Suárez, D. M. Pelletier, and R. T. Fahey. 2004a. Ecosystem consequences of exotic earthworm invasion of north temperate forests. Ecosystems 7:1-12.

Bohlen, P. J., D. M. Pelletier, P. M. Groffman, T. J. Fahey, and M. C. Fisk. 2004b. Influence of earthworm invasion on redistribution and retention of soil carbon and nitrogen in northern temperate forests. Ecosystems 7:13-27.

Bohlen, P. J., S. Scheu, C. M. Hale, M. A. McLean, S. Migge, P. M. Groffman, and D. Parkinson. 2004c. Non-native invasive earthworms as agents of change in northern temperate forests. Frontiers in Ecology and the Environment $2: 427-435$.
Bouché, M. B., and R. H. Gardner. 1984. Earthworm functions: population estimation techniques. Revue d'Ecologie et de Biologie du Sul 21:37-63.

Butt, K. R., and V. Nuutinen. 1998. Reproduction of the earthworm Lumbricus terrestris Linné after the first mating. Canadian Journal of Zoology 76:104-109.

Darwin, C. 1883. The formation of vegetable mould through the actions of worms, with observations on their habits. D. Appleton, New York, New York, USA.

Dufrêne, M., and P. Legendre. 1997. Species assemblages and indicator species: the need for a flexible asymmetrical approach. Ecological Monographs 67:345-366.

Dunger, W. 1989. The return of soil fauna to coal mined areas in the German Democratic Republic. Page 547 in J. D. Majer, editor. Animals in primary succession: the role of fauna in reclaimed lands. Cambridge University Press, Cambridge, UK and New York, New York, USA.

Dymond, P., S. Scheu, and D. Parkinson. 1997. Density and distribution of Dendrobaena octaedra (Lumbricidae) in aspen and pine forests in the Canadian Rocky Mountains (Alberta). Soil Biology and Biochemistry 29:265-273.

Edwards, C. A., editor. 2004. Earthworm ecology. Second edition. CRC Press, Boca Raton, Florida, USA.

Edwards, C. A., and P. J. Bohlen. 1996. Biology and ecology of earthworms. Chapman and Hall, London, UK.

Edwards, C. A., and J. R. Lofty. 1972. Biology of earthworms. Chapman and Hall, London, UK.

Ehrenfeld, J. G., and N. Scott. 2001. Invasive species and the soil: effects on organisms and ecosystem processes. Ecological Applications 11:1259-1260.

Engeman, R. M., N. P. Groninger, and D. C. Vice. 2003. A general model for predicting brown tree snake capture rates. Envirometrics 14:295-305.

Fisk, M. C., T. J. Fahey, P. M. Groffman, and P. J. Bohlen. 2004. Earthworm invasion, fine-root distributions, and soil respiration in north temperate forests. Ecosystems 7:55-62.

Frelich, L., C. Hale, S. Scheu, A. Holdsworth, L. Heneghan, P. Bohlen, and P. Reich. 2006. Earthworm invasion into previously earthworm-free temperate and boreal forests. Biological Invasions 8:1235-1245.

Gates, G. E. 1982. Farewell to North American Megadriles. Megadrilogica 4:12-77.

Groffman, P. M., P. J. Bohlen, M. C. Fisk, and T. J. Fahey. 2004. Exotic earthworm invasion and microbial biomass in temperate forest soils. Ecosystems 7:45-54.

Gundale, M. J. 2002. Influence of exotic earthworms on the soil organic horizon and the rare fern Botrychium mormo. Conservation Biology 16:1555-1561.

Gundale, M. J., W. M. Jolly, and T. H. DeLuca. 2005. Susceptibility of a northern hardwood forest to exotic earthworm invasion. Conservation Biology 19:1075-1083.

Hale, C. M., L. F. Frelich, and P. B. Reich. 2004. Allometric equations for estimation of ash-free dry mass from length measurements for selected European earthworm species (Lumbricidae) in the western Great Lakes region. American Midland Naturalist 151:179-185.

Hale, C. M., L. F. Frelich, and P. B. Reich. 2005a. Exotic European earthworm invasion dynamics in northern hardwood forests of Minnesota, USA. Ecological Applications 15:848-860.

Hale, C. M., L. F. Frelich, and P. B. Reich. 2006. Changes in hardwood forest understory plant communities in response to European earthworm invasions. Ecology 87:1637-1649.

Hale, C. M., L. F. Frelich, P. B. Reich, and J. Pastor. $2005 b$. Effects of European earthworm invasion on soil characteristics in northern hardwood forests of Minnesota, U.S.A. Ecosystems 8:911-927.

Hendrix, P. F., and P. J. Bohlen. 2002. Exotic earthworm invasions in North America: ecological and policy implications. BioScience 52:801-811. 
Holmstrup, M., B. T. Hansen, A. Nielsen, and I. K. Østergaard. 1990. Frost tolerance of lumbricid earthworm cocoons. Pedobiologia 34:361-366.

Kalisz, P. J., and D. B. Dotson. 1989. Land-use history and the occurrence of exotic earthworms in the mountains of eastern Kentucky. American Midland Naturalist 122:288-297.

Lawrence, A. P., and M. A. Bowers. 2002. A test of the 'hot' mustard extraction method of sampling earthworms. Soil Biology and Biochemistry 34:549-552.

Littell, R. C., G. A. Milliken, W. W. Stroup, and R. D. Wolfinger. 1996. SAS system for mixed models. SAS Institute, Inc., Cary, North Carolina, USA.

Liu, Z. G., and X. M. Zou. 2002. Exotic earthworms accelerate plant litter decomposition in a Puerto Rican pasture and a wet forest. Ecological Applications 12:1406-1417.

Mack, R. N., D. Simberloff, W. M. Lonsdale, H. Evans, M. Clout, and F. A. Bazzaz. 2000. Biotic invasions: causes, epidemiology, global consequences, and control. Ecological Applications 10:689-710.

Marinissen, J. Y. C., and F. van den Bosch. 1992. Colonization of new habitats by earthworms. Oecologia 91:371-376.

McCune, B., and J. B. Grace. 2002. Analysis of ecological communities. MjM Software Design, Gleneden Beach, Oregon, USA.

McCune, B., and M. J. Mefford. 1999. PC-ORD. Multivariate analysis of ecological data. MjM Software, Gleneden Beach, Oregon, USA.

McLean, M. A., and D. Parkinson. 1998. Impacts of the epigeic earthworm Dendrobaena octaedra on oribatid mite community diversity and microarthropod abundances in pine forest floor: a mesocosm study. Applied Soil Ecology 7:125-136.

McLean, M. A., and D. Parkinson. 2000. Field evidence of the effects of the epigeic earthworm Dendrobaena octaedra on the micro-fungal community in pine forest floor. Soil Biology and Biochemistry 32:351-360.

Mielke, P. W., and K. J. Berry. 2001. Permutation methods: a distance function approach. Springer, New York, New York, USA.

Migge, S. 2001. The effect of earthworm invasion on nutrient turnover, microorganisms and microarthropods in Canadian aspen forest soil. Technische Universität Darmstadt, Darmstadt, Germany.

Morgenweck, R. O., and W. H. Marshall. 1982. Earthworms of two Minnesota forests. Minnesota Academy of Science 48: $18-21$.

Nachtergale, L., K. Ghekiere, A. D. Schrijver, B. Muys, S. Luyssaert, and N. Lust. 2002. Earthworm biomass and species diversity in windthrow sites of a temperate lowland forest. Pedobiologia 46:440-451.

Nielson, G. A., and F. D. Hole. 1964. Earthworms and the development of coprogenous $A_{1}$ horizons in forest soils of Wisconsin. Soil Science Society of America Proceedings 28: 426-430.

Parendes, L. A., and J. A. Jones. 2000. Role of light availability and dispersal in exotic plant invasion along roads and streams in the H. J. Andrews Experimental Forest, Oregon. Conservation Biology 14:64-75.
Reynolds, J. W. 1977. The earthworms (Lumbricidae and Sparganophilidae) of Ontario. The Royal Ontario Museum, Toronto, Canada.

Reynolds, J. W. 1995. Status of exotic earthworm systematics and biogeography in North America. Pages 1-28 in P. F. Hendrix, editor. Earthworm ecology and biogeography in North America. CRC Press, Boca Raton, Florida, USA.

SAS Institute. 2002. JMP, version 5.0.1a. SAS Institute, Cary, North Carolina, USA.

Scheu, S., and D. Parkinson. 1994. Effects of invasion of an aspen forest (Canada) by Dendrobaena octaedra (Lumbricidae) on plant growth. Ecology 75:2348-2361.

Schwert, D. P. 1990. Oligochaeta: Lumbricidae. Pages 341-356 in D. L. Dindal, editor. Soil biology guide. John Wiley and Sons, New York, New York, USA.

Shakir, S. H., and D. L. Dindal. 1997. Density and biomass of earthworms in forest and herbaceous microecosystems in central New York, North America. Soil Biology and Biochemistry 29:275-285.

Simberloff, D., editor. 1989. Which insect introductions succeed and which fail? John Wiley and Sons, Chichester, UK.

Sims, R. W., and B. M. Gerard. 1999. Earthworms: notes for the identification of British species. Linnean Society of London and Estuarine and Coastal Sciences Association, Shrewsbury, UK.

Suárez, E. R., D. M. Pelletier, T. J. Fahey, P. M. Groffman, P. J. Bohlen, and M. C. Fisk. 2004. Effects of exotic earthworms on soil phosphorus cycling in two broadleaf temperate forests. Ecosystems 7:28-44.

Suárez, E. R., G. Tierney, T. J. Fahey, and F. Fahey. 2006. Exploring patterns of exotic earthworm distribution in a temperate hardwood forest in south-central New York, U.S.A. Landscape Ecology 21:297-306.

Tiunov, A. V., C. M. Hale, A. R. Holdsworth, and T. S. Perel. 2006. Invasion patterns of Lumbricidae into the previously earthworm-free areas of northeastern Europe and the western Great Lakes region of North America. Biological Invasions 8:1223-1234.

Tyser, R. W., and C. A. Worley. 1992. Alien flora in grasslands adjacent to road and trail corridors in Glacier National Park, Montana (U.S.A.). Conservation Biology 6:253-262.

Wardle, D. A., R. D. Bardgett, J. N. Klironomos, H. Setala, W. H. van der Putten, and D. H. Wall. 2004. Ecological linkages between aboveground and belowground biota. Science 304:1629-1633.

Watkins, R. Z., J. Chen, J. Pickens, and K. D. Brosofske. 2003. Effects of forest roads on understory plants in a managed hardwood landscape. Conservation Biology 17:411-419.

Wilcke, D. E. von 1952. On the domestication of the 'soilution' earthworm. Anzeiger fur Schädlingskunde 25:107-109.

Williamson, M. H. 1996. Biological invasions. First edition. Chapman and Hall, London, UK and New York, New York, USA.

Wolfinger, R. D. 1999. Fitting nonlinear mixed models with the new NLMIXED procedure. Pages $1-10$ in Proceedings of the 24th Annual SAS Users Group International Conference (SUGI 24), Paper 287. SAS Institute, Cary, North Carolina, USA.

\section{APPENDIX A}

Additional analytical details regarding treatment of lost samples and random intercept logistic normal regression models (Ecological Archives A017-070-A1).

\section{APPENDIX B}

Two tables and four figures showing indicator values of each earthworm taxonomic group for species assemblages, habitat conditions by earthworm assemblages, ash-free dry mass of earthworm taxonomic groups, and cluster analysis dendrograms for the Chequamegon and Chippewa National Forests (Ecological Archives A017-070-A2). 